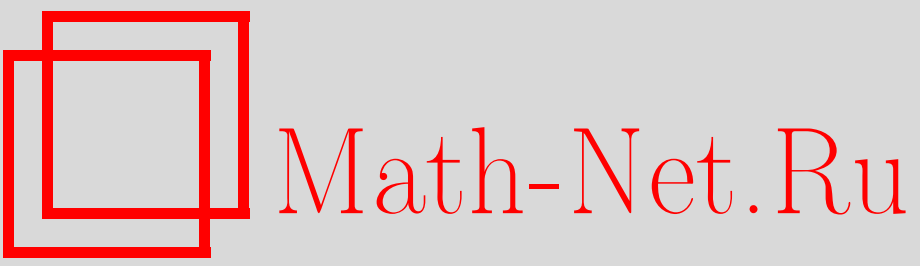

K 70-летию А. А. Логунова, ТMФ, 1997, том 110, номер 1, 3

DOI: https://doi.org/10.4213/tmf2076

Использование Общероссийского математического портала Math-Net.Ru подразумевает, что вы прочитали и согласны с пользовательским соглашением

http://www.mathnet.ru/rus/agreement

Параметры загрузки:

IP : 54.210 .77 .194

26 апреля 2023 г., 13:50:08 


\section{К 70-летию А. А. Логунова}

30 декабря 1996 года исполнилось 70 лет академику Анатолию Алексеевичу Логунову. Редакционная коллегия журнала "Теоретическая и математическая физика" сердечно поздравляет главного редактора журнала с юбилеем и желает ему доброго здоровья и дальнейших творческих успехов. 